\title{
Is Our Schooling System Broken?
}

\section{Leon Benade $^{1} \cdot$ Nesta Devine ${ }^{1} \cdot$ Georgina Stewart $^{1}$}

Published online: 12 April 2021

(c) New Zealand Association for Research in Education 2021

In his 2019 response to the report of Tomorrow's Schools Taskforce, the Minster of Education stated in his Foreword: "When we announced the Independent Review of Tomorrow's Schools, our starting point wasn't that the schooling system was broken" (Ministry of Education, 2019a, 2019b, p. 3. Emphasis added). Recent media reports suggest the opposite, highlighting serious, systemic problems related to education resourcing. On 2 March 2021, Radio New Zealand reported a New Zealand Principals' Federation (NZPF) call to school principals to defy MOE directives that they enrol violent children who have been excluded from other schools (Gerritsen, 2021). NZPF's underlying rationale for making such a controversial call is the inadequate resourcing provided by the MOE to schools to support excluded students, while the cited report contains other evidence of principals' resistance and frustration.

Almost three weeks later, it was reported (Nicol-Williams, 2021) that a New Zealand Educational Institute (NZEI) survey of Early Childhood employers and staff had found significant impacts arising from teacher shortages in the sector. The majority of the 305 respondents indicated that these shortages were having negative impacts on both their teaching and the children under their care. In the face of these shortages, it was reported that required teacher:child ratios are being ignored, leading the NZEI to suggest that this sector is at a critical juncture (Nicol-Williams, 2021).

A further NZEI initiative is its recent launch of Pūaotanga (NZEI, 2021). This independent staffing entitlement review includes a panel chaired by Steve Maharey. Its remit is to study the under resourcing of schools' staffing entitlements, and to that end, is taking oral and written submissions. Under-resourced schools are plagued by insufficient staffing and consequently find themselves unable to meet student learning and pastoral needs. This applies especially to children with special learning needs. Once concluded, the panel will summarise its findings and make pertinent recommendations aimed at improving staffing entitlements in the primary sector.

The questions raised are vexing, and some of the suggested solutions do not, on their own, appear to address the problems mentioned. For example, the media

Leon Benade

leon.w.benade@aut.ac.nz

1 Auckland University of Technology, Auckland, New Zealand 
article in relation to the Early Childhood sector (Nicol-Williams, 2021) suggested that higher salaries would help, yet it is not clear how this would solve the teacher:child ratio. Attracting teachers (through salary incentives) to work in a sector that may be struggling with other systemic issues is not likely to compensate in the long-run for the impacts of those issues on teachers' job satisfaction or attainment of personal professional goals. Indeed, higher salaries may still not be enough to attract and/or retain people in the profession.

The points raised here are a reminder that there are fundamental issues that continue to plague all levels of the education system in Aotearoa New Zealand. With particular reference to the compulsory schooling sector, these are notable:

- A devolved education system

- Performative measures that 'discipline' schools to do more with less

- The calculation of staffing entitlement based on ratios that ignore realities on the ground (such as dealing with challenging behaviours or complex learning needs in mainstream settings)

- Inadequate allowances for special needs funding in operations grants

- An unhealthy reliance on international student income to plug schools' budget shortfalls

Inequitable provisioning and outcomes for schools are driven by the factors above, and are exacerbated by pressure on a limited tax base and concomitantly, political promises made on the hustings to limit tax increases on individuals. Who benefits in such a skewed system? Certainly, those who can pay more to maintain 'standards' in their schools, measured by such criteria as available technology, opportunities for wider educational opportunities, and greater resourcing for special needs students. The work currently conducted by the NZEI sheds light onto a system that is a dismal failure for many and highlights the critical need to re-evaluate the fundamentals of how the education system in New Zealand is constituted and funded.

The Tomorrow's Schools Independent Taskforce (2019) was an opportunity to address some of these issues. Its authors suggested that a desirable education system is one able to elevate children's' rights to an education, secure their best interests and pursue social justice. To achieve these aspirational goals, suggested the Taskforce, such a system "allocates resources accordingly" (2019, p. 8). The Taskforce believed and suggested that the status quo would need to be disturbed to attain these aspirations.

Among the grounds for this suggestion is a recent UNICEF report that ranked Aotearoa New Zealand "as 33 out of 38 developed countries for its overall educational inequality” (Tomorrow's Schools Independent Taskforce, 2019, p. 13, citing UNICEF Office of Research, 2018), and other cited research pointing to low school attendance rates, a worrying incidence of bullying and racism, and steadily declining scholastic performance as measured by PISA tests and national monitoring. According to the Taskforce, "current system settings have not been able to shift these disparities" (2019, p. 14). This sobering reading counterbalances the vague 'wellbeing' discourse that is central to existing government policy-making, 
not to mention the idea that Aotearoa New Zealand has a world-leading education system.

The Taskforce presented eight recommendations, including 'Improved Resourcing', recognising that "there is a gap between what Aotearoa New Zealand expects of its public education system in terms of equity and excellence, and its resourcing" (p. 66). This recommendation called for continued action to implement the 'Equity Index', already slated to replace the decile-funding mechanism with a methodology that "estimates the extent to which children grow up in socio-economically disadvantaged circumstances that we know to be associated with their likelihood of achieving in education" (Ministry of Education, 2021). Its second proposed action addressed the disparity between primary and secondary schools in respect of leadership and counselling staffing levels, while a third action aimed to provide a broader range of incentives to support schools and kura in 'more complex contexts' (Tomorrow's Schools Independent Taskforce, 2019). These actions, while significant, are, however, not directly concerned with the provision of general staffing, and support staff. Missing, for example, is any reference to class sizes or average staffing ratios.

In its response, the government has agreed to prioritise the Equity Index recommendation, but has placed the other two 'improved resourcing' recommendations somewhat on the back burner, specifically the improvement of entitlements for school leadership and counselling positions and the installation of incentives to attract people to (and retain staff in) 'hard-to-staff' schools (Ministry of Education, 2019a, 2019b).

The Taskforce made bold suggestions intended to disturb the status quo. Nothing less will address critical systemic issues. The response by the Minister of Education to the Tomorrow's Schools Taskforce report suggests that, indeed, the Taskforce recommendations have been, in the main, taken up. A telling frame for the government's response, however, is the statement from the Minster of Education, quoted earlier, a statement that makes sense of what seems to be a tepid response focussing on creating "a more networked, responsive and supported system" (Ministry of Education, 2019a, 2019b, p. 12) by:

- Creating an Education Service Agency (ESA) that will attempt to bring the Ministry of Education support closer to schools (through localisation and regionalisation)

- Providing greater rigour to the development of school principal leadership

- And providing strategic centralisation of matters related to property (development, procurement and maintenance) and enrolment schemes.

The distraction of Covid aside, there have been significant developments in 2020, including the passing into legislation of the Education and Training Act 2020 and the Education (Vocational Education and Training Reform) Amendment Act 2020 (which enabled the establishment of the New Zealand Institute of Skills and Technology). Work has continued on the NCEA Change Programme, on adding history as a compulsory element in The New Zealand Curriculum, and currently, on preparing the review and 'refresh' of the national curriculum (https://www.education.govt. nz/our-work/information-releases/issue-specific-releases/national-curriculum-refre 
$\mathrm{sh} /$ ). Despite this level of activity, however, critical areas of education provision continue to stagnate, culminating in the earlier mentioned media stories of the past month. The educator frustrations these stories illustrate will not be smoothed by the high-level changes recently launched-while these may be necessary improvements to the education system, they seem to offer little to support teachers' work. Maintaining and developing a successful education system depends on ensuring that those experiencing the system first-hand do not perceive it to be broken.

\section{References}

Gerritsen, J. (2021, March 2). Schools told to consider refusing enrolment of violent children by Principals' Federation. Radio New Zealand. https://www.rnz.co.nz/news/national/437447/schools-told-toconsider-refusing-enrolment-of-violent-children-by-principals-federation

Ministry of Education. (2019). Supporting all schools to succeed: Reform of the Tomorrow's Schools system. Ministry of Education. https://conversation.education.govt.nz/assets/TSR/November-2019/ TSR-Government-Response-WEB.pdf

Ministry of Education. (2021). Equity Index. https://www.education.govt.nz/our-work/information-relea ses/issue-specific-releases/equity/

New Zealand Educational Institute (NZEI). (2021). Pūaotanga: An independent review into primary school staffing. https://www.puaotanga.org.nz/?fbclid=IwAR13gryC254CRIpyZuP0g56h6Igc5JBzh Jvne4ZiKD5yp0yw0bK2aa83DeA

Nicol-Williams, K. (2021, March 21). 'Diabolical. Unstable and stressful' - ECE teacher shortage affecting children, staff, survey finds. Television New Zealand. https://www.tvnz.co.nz/one-news/ new-zealand/diabolical-unstable-and-stressful-ece-teacher-shortage-affecting-children-staff-surveyfinds?fbclid=IwAR1gbVqq4Po6epQ7Q5NS42GX5xY62vzKal0vf6vTgd8AfgcwTQErnQ-wPp0

Tomorrow's Schools Independent Taskforce (2019). Our schooling futures: Stronger together. Whiria ngā kura tūātinitini. Final report by the Tomorrow's Schools Independent Taskforce. Ministry of Education. https://conversation-space.s3-ap-southeast-2.amazonaws.com/Tomorrows+Schools+ FINAL+Report_WEB.pdf

Publisher's Note Springer Nature remains neutral with regard to jurisdictional claims in published maps and institutional affiliations. 